\title{
TIBIAL NERVE CONDUCTION IN PATIENTS WITH RESTLESS LEGS SYNDROME
}

\section{Huzursuz Bacak Sendromlu Hastalarda Tibial Sinir Iletimi}

\author{
Hikmet SAÇMACI ${ }^{1}$ iD, Mesude KISLL $\dot{I}^{2}$ \\ ${ }^{1}$ Bozok University School of Medicine, Department of Neurology, YOZGAT, TÜRKIYE \\ ${ }^{2}$ Sivas State Hospital, Department of Neurology, SIVAS, TÜRKIYE
}

\begin{abstract}
Objective: Pathogenesis and clinical correlations of restless legs syndrome are diverse. Its presentation with the neuropathy clinic can be confusing. The aim of this study is to review nerve conductions of lower extremities in patients with restless legs syndrome and to identify possible differences.
\end{abstract}

Material and Methods: Distal nerve conductions of the lower extremities were evaluated cross-sectionally in 32 patients diagnosed with restless legs syndrome according to the battery of diagnosis for restless legs syndrome and additional symptoms were questioned. Motor and sensory nerve conductions were assessed with standard protocol. The demographic, clinical features and nerve conductions of restless legs syndrome patients who were on treatment were compared. The results were compared with the healthy control group $(n=29)$.

Results: Neurological examinations of all patients were within normal limits. Both groups were similar in age and gender. Peroneal and sural nerve conduction parameters were not different in both groups ( $p>0.05)$. However, the tibial nerve parameters showed a decrease in amplitude and prolongation in distal latency was observed in the patients $(p=0.003, p<0.001)$. We found that the tibial nerve conduction velocity was slower in the patient group $(\mathrm{p}<0.001)$.

Conclusion: The results show that in restless legs syndrome patients, tibial nerve conduction parameters may vary according to the control group. Before starting the necessary and appropriate treatment in restless legs syndrome patients, it should be noted that, even if the etiological investigation has been done before, it may be important to renew the tests for an optimal treatment plan.

Keywords: Restless legs syndrome, nerve conduction studies, tibial nerve, neuropathy

\begin{abstract}
Amaç: Huzursuz bacak sendromunun patogenez ve klinik korelasyonları çok çeşitlidir. Sendromun nöropati kliniği ile prezentasyonu kafa karıştırıcı olabilir. $\mathrm{Bu}$ çalışmanın amac1, huzursuz bacak sendromlu hastalarda alt ekstremite sinir iletilerini gözden geçirmek ve olası farklılıkları belirlemektir.

Gereç ve Yöntemler: Huzursuz bacak sendromu ve ek semptomlarının sorgulandığ bacak sendromu tanis1 alan ve tedavisi devam eden hastaların kesitsel olarak alt ekstremite distal sinir iletileri değerlendirildi. Motor ve duyu siniri iletileri standart protokol ile gerçekleştirildi. Dopamin agonisti tedavisi devam eden huzursuz bacak sendromu hastalarının demografik, klinik özellikleri ile sinir iletileri değerlendirildi. Sonuçlar sağlıklı kontrol grubu $(n=29)$ ile karşılaştırıldı.

Bulgular: Tüm hastaların nörolojik muayeneleri normal sınırlardaydı. Her iki grup yaş ve cinsiyet olarak benzer özellikteydi. Hasta grubunda peroneal ve sural sinir ileti parametreleri sağlıklı kontrol grubu ile kiyaslanınca farklılık göstermiyordu ( $>00.05)$. Ancak tibial sinir parametrelerine bakıldığında kontrol grubuna göre amplitüdde azalma ve distal latansta uzama olduğu görüldü $(\mathrm{p}=0.003, \mathrm{p}<0.001)$. Tibial sinir ileti hızının da hasta grubunda daha yavaş olduğunu bulduk $(\mathrm{p}<0.001)$.

Sonuç: Sonuçlar göstermektedir ki huzursuz bacak sendromu hastalarında tibial sinir ileti parametreleri kontrol grubuna göre değişebilir. Huzursuz bacak sendromu hastalarının kullandıkları tedaviyi tekrarlamadan önce, etiyolojik aydınlatma daha önce yapılmış bile olsa optimal tedavi planı için tetkiklerin yenilenmesinin önemli olabileceği unutulmamalıdır.
\end{abstract}

Anahtar Kelimeler: Huzursuz bacak sendromu, sinir iletim çalışmaları, tibial sinir, nöropati 


\section{INTRODUCTION}

Restless Leg Syndrome (RLS) is a sensorimotor disorder characterized by distressing sensations in the legs and an overwhelming urge to move the legs (1). The prevalence of RLS in the general population differs according to population characteristics (2). All versions of the criteria preserves the essential clinical features: sensory symptoms - restlessness (urge to move) and unpleasant sensations (paresthesia, pain)-and motor symptoms (3). Motor symptoms are involuntary periodic limb movements that occur while awake and at rest. These movements consist of dorsiflexions of the foot, sometimes associated with flexion of the knees and hips (4). The main complaint of these patients is leg discomfort during the day and motor components tend to be underestimated (5).

RLS can occur either as primary or secondary. Secondary RLS is associated with several disorders such as diabetes mellitus, renal failure, iron deficiency and peripheral neuropathy, which draws attention to the width of the diagnostic window $(6,7)$. Furthermore, sensory and motor nerve conduction and biopsy specimen abnormalities have been reported in numerous patients with RLS (8-10). There is a significant diversity with regard to the prevalence of RLS in neuropathies, and the reported prevalence ranges from $5.2 \%$ to $54 \%$ (11). However, there are also contrary results in the literature $(12,13)$ and electron microscopic examination did not show a structural abnormality in nerve endings in patients with idiopathic RLS (14). The prevalence of RLS may increase in the presence of family history or concomitant comorbidities (11).

RLS symptoms are often hard to characterize and patients find it difficult to describe their symptoms. Symptoms in neuropathy can be similar or overlapping, especially in axonal neuropathy and small fiber neuropathy (15). There are very few studies on the recognizability of RLS and the relationship between neuropathy and RLS due to differences in the neuropathy spectrum (15). Current evidence covers a broad spectrum of pathophysiological, population-based (cross-sectional or longitudinal) studies, clinical trials, and treatment trials. However the question of whether RLS is a rather primary disorder or comorbidity remains unresolved (3). Furthermore, qualitative analysis of electrophysiological patterns of leg movements is crucial in demonstrating the pathophysiological mechanisms of RLS (5).

This study was planned to screen for possible nerve conduction disorders that may occur during the diagnosis and treatment of RLS. Our aim was to perform electrophysiological examination of nerve conduction in the lower extremities in patients with RLS diagnosis and to investigate their clinical correlations, findings in terms of secondary RLS and the need for review the diagnosis at this point.

\section{MATERIALS AND METHODS}

The study was approved by the Local Ethics Committee (Kırıkkale University Ethics Committe of Clinical Research; date: 19.01.2016, issue number: 01-02). The Helsinki declaration was complied with, and informed consent was obtained from each patient. Patients with a diagnosis of RLS who admitted to the outpatient clinic for routine follow-up and who were on treatments were asked to answer the following standardized questions (2):

- The urge to move the legs, accompanied by distressing and unpleasant sensations in the legs,

- These impulses or sensations begin or worsen during periods of rest, such as recumbency or sitting,

- These impulses or sensations are partially or completely relieved by movements such as walking or stretching, at least as long as the activity continues.

- These symptoms and sensations occur or get worse in the evening or at night rather than daytime. 
- The emergence of the above features is not attributed to primary symptoms (eg. myalgia, venous stasis, leg edema, arthritis, leg cramps, positional discomfort, habitual foot tapping) of another medical or behavioral condition.

All patients met the clinical diagnostic criteria of restless legs syndrome according to the above database (2). All questions were answered by face-to-face interview. All of the patients were questioned for demographic parameters such as age, comorbidity, medication history and alcohol or drug use. Neuropathy and trauma were investigated in the legs, and it was assessed that there was no history of previous surgery, inflammatory metabolic disease or degenerative disease (especially history of diabetes and cardiovascular risk factors and cerebrovascular disease).

After an extensive neurological examination, two motor conduction studies (tibial and peroneal nerve) and one sensory study (sural nerve) were performed in the lower extremities using a Nihon Kohden EMG device (Neuropack 2, Nihon Kohden, Tokyo, Japan). Studies were performed by stimulating the peroneal nerve in the fibular head, the tibial nerve in the popliteal fossa in the gastrocnemius muscle, the sural nerve between the lateral and medial heads of gastrocnemius muscles. Proximal and distal stimulations for tibial and peroneal motor nerves were performed as detailed below. Surface electrode recordings were used for motor and sural nerve sensory studies. All nerve conduction studies were performed by providing a comfortable foot position for the relevant leg while the subjects also lay in a comfortable position.

Antidromic sural sensory nerve action potentials (SNAPs): The active recording electrode was placed between the lateral malleolus and the Achilles tendon. The reference recording electrode was placed $3 \mathrm{~cm}$ distal to the active electrode. Stimulation was done $14 \mathrm{~cm}$ proximal to the active recording electrode on the distal posterolateral leg.
Peroneal compound muscle action potentials (CMAPs): We stimulated the recording electrode $8 \mathrm{~cm}$ proximal to the Extensor Digitorum Brevis muscle (EDB) on the dorsum of the ankle. We made the proximal stimulation behind the head of the fibula and maximum CMAPs were recorded.

Tibial compound muscle action potentials (CMAPs): The active electrode was placed in the abductor hallucis (AH) muscle belly and the reference electrode in the medial direction of the thumb, one finger width from the navicular bone of the foot to the plantar surface. Stimulation was performed from the posterior medial malleolus. After stimulating the nerve on the abductor pollicis brevis muscle and $\mathrm{AH}$ muscles, maximum CMAPs were recorded using surface electrodes.

The amplitude, latency and velocity parameters of the sural nerve were examined. SNAP latency was measured from the beginning of the first negative deflection and was used to calculate the conduction rate. To improve the signal-to-noise ratio, the average of at least 10 responses was obtained for sural nerve studies. CMAP amplitudes were measured from the peak of the negative deflection from baseline. The recordings were made with standard equipment settings using 5 $\mathrm{mV} /$ division, sweeping speed $5 \mathrm{~ms} /$ division, stimulus time $0.2 \mathrm{~ms}$, low frequency filter $10 \mathrm{~Hz}$, high frequency filter $5 \mathrm{KHz}$ stimulators. The skin temperature was controlled and maintained between $31^{\circ} \mathrm{C}$ and $34^{\circ} \mathrm{C}$ in all subjects. All nerve conduction studies were carried out in a warm room at $26-28^{\circ} \mathrm{C}$. As reference values, we used the recommended values of Preston et al (16).

\section{Statistical Analysis}

SPSS (version 20.0, released 2011; IBM Corp. Armonk, New York, USA) was used for all statistical analysis as well as frequencies and descriptive statistics for each variable. The distribution pattern was evaluated using the Kolmogorov-Smirnov normality test (K-S test). Correlations in abnormal distributions were performed with Spearman's correlation analysis. Analyzes with 
normal distributions were done with Pearson correlation analysis. Chi-square test was used for the analysis of categorical variables. The relationship of continuous variables between groups was compared with MannWhitney U test and Student's t-test. $p<0.05$ value was considered statistically significant.

\section{RESULTS}

A total of 61 subjects (29 controls and 32 patients) were included for analysis. The mean age of the control group (17.2\% male, $82.8 \%$ female) was $43.41 \pm 13.22$ years (range: 19-67 years); the mean age of the patient group ( $18.8 \%$ male, $81.2 \%$ female) was $44.75 \pm 11.89$ years (range: 18-61 years). Demographic characteristics were similar in both groups. The median duration of the disease in terms of RLS was 3 years and the 25th-75th percentile was between 2.25 and 5.75 years.

Regarding electrophysiological parameters, the findings of peroneal nerve and sural nerve conduction studies between the two groups did not differ statistically $(p>0.05)$. However, when the tibial nerve conduction values were examined, distal CMAPs median value was significantly lower than the control group values $(\mathrm{p}=0.003)$, and distal latency was significantly longer $(\mathrm{p}<0.001)$ (Table 1). Our other finding is that the tibial nerve conduction velocity was slower in the patient group $(\mathrm{p}<0.001)$ and this finding is consistent with normal data. Test values were within normal limits compared to our laboratory data.

Table 1: Patients' clinical and electrodiagnostics characteristics

\begin{tabular}{|c|c|c|c|c|}
\hline Characteristics & $\begin{array}{c}\text { Group 1: RLS patients } \\
(\mathrm{n}=32)\end{array}$ & $\begin{array}{c}\text { Group 2: Controls } \\
(\mathrm{n}=29)\end{array}$ & $\begin{array}{l}\text { Normal } \\
\text { values*** }\end{array}$ & $\mathbf{p}$ \\
\hline Age, in years & $44.75 \pm 11.89$ & $43.41 \pm 13.22$ & - & $0.681 *$ \\
\hline Gender (n) & $26 / 6$ & $24 / 5$ & - & 0.878 \\
\hline (Female/male) (\%) & $81.2 / 18.8$ & $82.8 / 17.2$ & & \\
\hline Body mass index $\left(\mathrm{kg} / \mathrm{m}^{2}\right)$ & $28(26-30)$ & $28(27-29)$ & - & 0.855 \\
\hline Duration of RLS, in years & $3(2.25-5.75)$ & - & - & - \\
\hline \multicolumn{5}{|l|}{ Tibial motor nerve } \\
\hline CMAP amplitude (mV) & $\begin{array}{c}11.97 \\
(9.29-13.38)\end{array}$ & $\begin{array}{c}17.07 \\
(12.60-17.10)\end{array}$ & $\geq 4$ & 0.003 \\
\hline Distal latency (ms) & $4.04 \pm 0.53$ & $3.59 \pm 0.37$ & $\leq 5.8$ & $0.000 *$ \\
\hline Velocity $(\mathrm{m} / \mathrm{s})$ & $\begin{array}{c}48.01 \\
(47.70-50.5) \\
\end{array}$ & $\begin{array}{c}52.15 \\
(51.35-52.15) \\
\end{array}$ & $\geq 41$ & 0.000 \\
\hline \multicolumn{5}{|l|}{ Peroneal motor nerve } \\
\hline CMAP amplitude (mV) & $\begin{array}{c}6.49 \\
(5.20-7.40)\end{array}$ & $\begin{array}{c}6.85 \\
(5.03-8.23)\end{array}$ & $\geq 2$ & 0.718 \\
\hline Distal latency (ms) & $\begin{array}{c}3.51 \\
(2.90-3.95)\end{array}$ & $\begin{array}{c}3.35 \\
(2.87-3.82)\end{array}$ & $\leq 6,5$ & 0.370 \\
\hline Velocity $(\mathrm{m} / \mathrm{s})$ & $\begin{array}{c}54.02 \\
(51.47-56.02)\end{array}$ & $\begin{array}{c}52.90 \\
(50.20-54.90)\end{array}$ & $\geq 44$ & 0.155 \\
\hline \multicolumn{5}{|l|}{ Sural sensory nerve } \\
\hline SNAP amplitude (mV) & $\begin{array}{c}17.23 \\
(15.20-18.12)\end{array}$ & $\begin{array}{c}16.36 \\
(11.90-19.15)\end{array}$ & $\geq 6$ & 0.172 \\
\hline Peak latency (ms) & $2.40 \pm 0.29$ & $2,37 \pm 0.32$ & $\leq 4.4$ & $0.691 *$ \\
\hline Velocity $(\mathrm{m} / \mathrm{s})$ & $56.77 \pm 6.23$ & $59.90 \pm 7.39$ & $\geq 40$ & $0.081 *$ \\
\hline
\end{tabular}

Data expressed as mean \pm standard deviation/ median (25th-75th percentil) or as number (\%).

* Student's T test, others, Mann-Whitney U test. Bold values are statistically significant $(\mathrm{p}<0.05)$. **For the reference values of the nerve conductions, we used the recommended values Preston et al. 


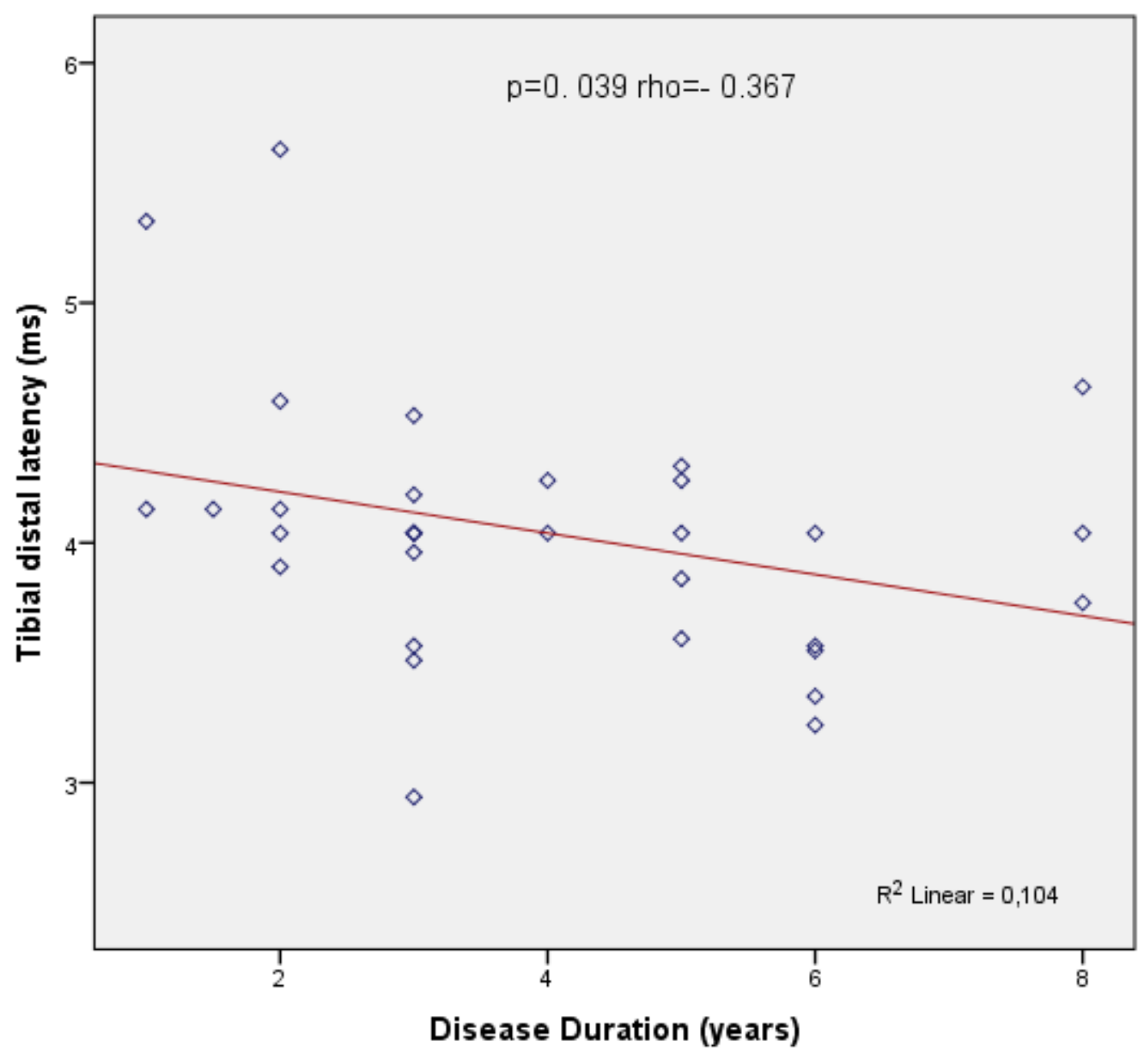

Figure 1: Correlation analysis of tibial nerve distal latency and duration of symptoms.

\section{DISCUSSION}

When the relationship of disease duration and tibial nerve amplitude, latency and conduction velocity correlations were examined, the most significant correlation was related to distal latency prolongation $(\mathrm{p}=0.039$, rho $=-0.367)$ (Figure 1). Our other correlation analyzes did not reveal any statistically significant finding.

Furthermore, when we correlated our tibial conduction values with age and body mass index, there was no statistically significant relationship in amplitude, latency and conduction rates in patient group compared to the control group ( $p>0.05$ for all).
Here we present the data of a clinical trial of the electrophysiological peroneal, tibial and sural peripheral nerve conduction studies in a cohort of RLS patients. As the general symptoms on the disease are mostly related to the lower distal extremities, the study plan was created in this way.

The first of our results is that most affected nerve among these three lower peripheral nerves was tibial motor nerve. The second result is that the prolonged distal latency is negatively correlated by the prolonged disease duration. In addition, our patients had low amplitude and prolonged latency, however the conduction velocity was shorter than the controls. 
Despite devoted studies on RLS, less than $41 \%$ of serious symptomatic patients are reported as having true diagnosis of RLS by physicians (17). One of the reasons for the restriction in the diagnosis is that pathophysiology of this disease is largely unknown. RLS can be attributed to a multifactorial network disorder that includes many areas of the nervous system, from the spinal cord and peripheral nerves to the dopaminergic and glutamatergic nuclei of the central nervous system $(18,19)$. This anatomical diversity is due to the fact that RLS is intertwined with several different topographic, genetic and biochemical factors, isolated or in combination (20). A close association with these detailed disorders can also lead to missed diagnosis of true RLS. According to the Diagnostic and Statistical Manual of Mental Disorders (DSM-5) criteria, RLS appears to be a comorbidity disorder, and the genetic risk burden and comorbidities of patients constitute the cumulative risk of RLS manifestation (3).

The role of peripheral nerve damage in causality and increased symptoms in RLS remains uncertain. Initially, an increase in the prevalence of RLS (up to $40 \%$ for patients) was reported in patients with polyneuropathy, however exclusion of RLS-mimicking conditions due to neuropathic complaints alone (cramps or paraesthesia occurring irrelevant to resting state) reduced the prevalence of RLS to $12.2 \%$ in patients with neuropathy (compared to $8.2 \%$ in control patients) $(21,22)$. As a result, RLS may occur due to other comorbidities that affect the sensorimotor pathways from the cerebrum to the spinal cord and peripheral nerves (3).

Peripheral neuropathy can be considered as an umbrella term covering many forms of paresthesia with different etiology. This definition may include many diseases such as diabetic sensory polyneuropathy, demyelinating neuropathy, hereditary neuropathy, and small fiber sensory neuropathy, all of which have been reported with RLS (23). Furthermore, based on the knowledge that peripheral nerve entrapment is an important component of RLS, Anderson et al. showed that surgical decompressions of common and superficial fibular nerves are correlated with improvement in RLS-related disease symptoms (24). Similarly, Kocabicak et al showed improvement in symptoms after decompression surgery in patients with lumbar radiculopathy accompanied by RLS symptoms (25).

In their research on polyneuropathy and RLS severity, Pitarokoili et al. showed that distal latency of the tibial nerve and tibial motor degeneration were inversely proportional to the severity of RLS symptoms (20). However, in their study, the fact that iron stores of the patients were unknown and the presence of comorbidities in the patients may be important limitations. In this study, we showed that tibial nerve conduction data were affected in patients who are on routine dopamine agonist treatment compared to healthy controls. Iron and vitamin status in patients who were included in the study were within normal limits and tibial nerve distal latency was deteriorated by elongation of disease duration. However, there was no significant correlation between tibial nerve amplitude or velocity and disease duration. Here, perhaps, symptom severity, genetic or molecular disorder origin or the presence of secondary disorders such as accompanying lumbosacral plexopathy are crucial rather than disease duration. As a result, it seems more appropriate to review the diagnosis with certain periods in these patients who receive dopamine agonist treatment and to treat them according to etiology rather than RLS symptoms. The reason for this is that in a patient who is assumed to have augmentation, perhaps it will be necessary to review the optimal treatment. If the patient's complaints increase over time with dopamin agonist treatment, it should be kept in mind that augmentation may occur and this will be more complex in follow-up and treatment (2).

In the review of recent studies, there are literature data regarding the absence of electrophysiological impairment in terms of primary RLS, however there are also studies with contrary results (26). Various studies show differences such as study design and subtypes of 
polyneuropathy evaluated. However, we think that etiological re-evaluation will be necessary in terms of switching to different comorbid diagnoses and implementing a treatment plan. In our study, tibial nerve amplitude decreased, latency was prolonged, and conduction speed was reduced. We did not find any difference in the peroneal and sural nerves compared to the control group. In fact, while the amplitude is expected to decrease in correlation with age, it has been shown that our data are not affected by age and body weight, and the correlation relationship we found emphasized the importance of disease duration.

In the diagnosis of neuropathy, signs of low amplitude of the sural nerve and/or low peroneal and/or tibial motor nerve velocity findings are encountered. As early signs of demyelinating neuropathy, markedly prolonged distal motor delay, very slow conduction velocity and prolonged CMAP time can be documented (27). Prolonged distal motor and sensory latency findings occur for tibial trap neuropathy at the tarsal level $(28,29)$. In our data, it was found that there was a difference in the tibial nerve compared to the control group, although it was within normal limits. Although all our findings except the slow conduction velocity in the tibial nerve were within the normal reference limits, our findings made us think that we should follow our patients more closely in terms of electrophysiological changes. In conclusion, even if neuropathy findings do not appear objectively, it would be important for these patients to be followed up clinically.

Some limitations of our study include scant number of patients and the absence of investigations for etiopathogenetic research. Longitudinal studies with more extensive NCS studies and needle EMG along with electromyographic analysis and radiological imaging of muscles would contribute to the literature. In our study, exclusion of the patients with comorbidities was actually an advantage. In this way, we believe that we only screened primary RLS patients.
In conclusion, regarding our cohort followed by the RLS clinic, we would like to emphasize that our electrophysiological nerve conduction data may be intertwined with changes in tibial nerve conduction findings and neurological re-evaluation with evaluations such as electrophysiological studies should not be neglected during the clinical follow-up.

All authors meet the ICMJE authorship criteria Conflict of Interests: The author(s) declared no potential conflicts of interest with respect to the research, authorship, and/or publication of this article.

Support and Acknowledgment: The authors did not receive any financial support from the Unit of Scientific Research.

Researchers' Contribution Rate Statement: ConceptDesign: HS, MK; Data Collection and Processing: HS, MK; Analysis and Interpretation: HS, MK; Literature Search: HS, MK; Writing Manuscript: HS; Critical Review: HS, MK.

Ethics Committe Aproval: K1rıkkale University Ethics Committe of Clinical Research; date: 19.01.2016, issue number: 01-02

\section{REFERENCES}

1. Akyol A, Kiylioglu N, Kadikoylu G, Bolaman AZ, Ozgel N. Iron deficiency anemia and restless legs syndrome: is there an electrophysiological abnormality? Clin Neurol Neurosurg. 2003;106(1):23-7.

2. Allen RP, Picchietti DL, Garcia-Borreguero D, Ondo WG, Walters AS, Winkelman JW et al. Restless legs syndrome/Willis-Ekbom disease diagnostic criteria: updated International Restless Legs Syndrome Study Group (IRLSSG) consensus criteria-history, rationale, description, and significance. Sleep Med. 2014;15(8):860-73.

3. Trenkwalder C, Allen R, Högl B, Paulus W, Winkelmann J. Restless legs syndrome associated 
with major diseases: a systematic review and new concept. Neurology. 2016;86(14):1336-43.

4. Michaud M, Lavigne G, Desautels A, Poirier G, Montplaisir J. Effects of immobility on sensory and motor symptoms of restless legs syndrome. Mov Disord. 2002;17(1):112-5.

5. Trenkwalder C, Bucher SF, Oertel WH. Electrophysiological pattern of involuntary limb movements in the restless legs syndrome. Muscle Nerve. 1996;19(2):155-62.

6. Fulda S, Wetter TC. Emerging drugs for restless legs syndrome. Expert opinion on emerging drugs. 2005;10(3):537-52.

7. Satija P, Ondo WG. Restless legs syndrome: pathophysiology, diagnosis and treatment. CNS Drugs. 2008;22(6):497-518.

8. Ondo W, Jankovic J. Restless legs syndrome: clinicoetiologic correlates. Neurology. 1996;47(6):1435-41.

9. Polydefkis M, Allen R, Hauer P, Earley CJ, Griffin J, McArthur JC. Subclinical sensory neuropathy in late-onset restless legs syndrome. Neurology. 2000;55(8):1115-21.

10. Iannacone S, Ferrini-Strambi L, Zucconi M. Peripheral nerve investigation in restless legs syndrome. J Neurol. 1994;241(Suppl 1):S156.

11. Nineb A, Rosso C, Dumurgier J, Nordine T, Lefaucheur JP, Creange A. Restless legs syndrome is frequently overlooked in patients being evaluated for polyneuropathies. Eur J Neurol. 2007;14(7):78892.

12. Teive HA, Munhoz RP, Barbosa ER. Professor KarlAxel Ekbom and restless legs syndrome. Parkinsonism Relat Disord. 2009;15(4):254-7.

13. Montplaisir J, Godbout R, Boghen D, DeChamplain J, Young S, Lapierre G. Familial restless legs with periodic movements in sleep: electrophysiologic, biochemical, and pharmacologic study. Neurology. 1985;35(1):130-4.

14. Gonzalez-Latapi P, Malkani R. Update on restless legs syndrome: from mechanisms to treatment. Curr Neurol Neurosci Rep. 2019;19(8):1-12.

15. Bastia JK, Bhoi SK, Kalita J, Misra UK. Neuropathy in a cohort of restless leg syndrome patients. J Clin Neurosci. 2015;22(8):1314-8.

16. Preston DC, Shapiro BE. Electromyography and neuromuscular disorders e-book: clinicalelectrophysiologic correlations. 3th ed. Netherlands. Elsevier Saunders, 2012.

17. Allen RP, Bharmal M, Calloway M. Prevalence and disease burden of primary restless legs syndrome: results of a general population survey in the United States. Mov Disord. 2011;26(1):114-20.

18. Hartmann M, Pfister R, Pfadenhauer K. Restless legs syndrome associated with spinal cord lesions. J Neurol Neurosurg Psychiatry. 1999;66(5):688-9.

19. Freeman AA, Rye DB. The molecular basis of restless legs syndrome. Curr Opin Neurobiol. 2013;23(5):895-900.

20. Pitarokoili K, Fels M, Kerasnoudis A, Tönges L, Gold R, Yoon MS. High-resolution nerve ultrasound and electrophysiological findings in restless legs syndrome. J Neuroimaging. 2018;28(5):506-14.

21. Rajabally YA, Shah RS. Restless legs syndrome in chronic inflammatory demyelinating polyneuropathy. Muscle Nerve. 2010;42(2):252-6.

22. Hanewinckel R, Drenthen J, van Oijen M, Hofman A, van Doorn PA, Ikram MA. Prevalence of polyneuropathy in the general middle-aged and elderly population. Neurology. 2016;87(18):1892-8.

23. Bastia JK, Bhoi SK, Kalita J, Misra UK. Neuropathy in a cohort of restless leg syndrome patients. J Clin Neurosci. 2015;22(8):1314-8. 
24. Anderson JC, Fritz ML, Benson JM, Tracy BL. Nerve decompression and restless legs syndrome: a retrospective analysis. Front Neurol. 2017;6(8):287.

25. Kocabicak E, Terzi M, Akpinar K, Paksoy K, Cebeci I, Iyigun O. Restless leg syndrome and sleep quality in lumbar radiculopathy patients. Behav Neurol. 2014;2014:245358.

26. Becker PM, Novak M. Diagnosis, comorbidities, and management of restless legs syndrome. Curr Med Res Opin. 2014;30(8):1441-60.

27. Sethi KD, Mehta SH. A clinical primer on restless legs syndrome: what we know, and what we don't know. Am J Manag Care. 2012;18(5 Suppl):S83-8.

28. Mastaglia FL. Tibial nerve entrapment in the popliteal fossa. Muscle Nerve. 2000;23(12):1883-6.

29. Neary KC, Chang E. Tarsal tunnel syndrome secondary to accessory musculature: a case report. Foot Ankle Spec. 2019;12(6):549-54. 